E International

\title{
Alternative Ways of Financing Infrastructure Investment: Potential for 'Novel' Financing Models
}

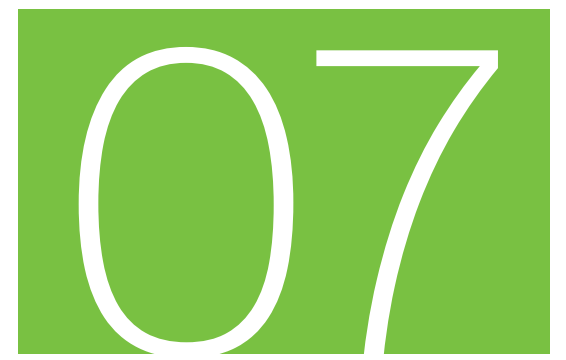

Discussion Paper 2012 • 07 Andrew Meaney, Peter Hope Oxera, UK 


\title{
Alternative ways of financing infrastructure investment
}

\author{
Potential for 'novel' financing models
}

\section{Discussion Paper No. 2012-7}

Prepared for the Roundtable on:

Public Private Partnerships for Funding Transport Infrastructure:

Sources of Funding, Managing Risk and Optimism Bias

(27-28 September 2012)

\author{
Oxera Consulting Ltd \\ Andrew Meaney and Peter Hope \\ Oxford, \\ United Kingdom
}

September 2012 


\section{INTERNATIONAL TRANSPORT FORUM}

The International Transport Forum at the OECD is an intergovernmental organisation with 54 member countries. It acts as a strategic think tank with the objective of helping shape the transport policy agenda on a global level and ensuring that it contributes to economic growth, environmental protection, social inclusion and the preservation of human life and well-being. The International Transport Forum organizes an annual summit of Ministers along with leading representatives from industry, civil society and academia.

The International Transport Forum was created under a Declaration issued by the Council of Ministers of the ECMT (European Conference of Ministers of Transport) at its Ministerial Session in May 2006 under the legal authority of the Protocol of the ECMT, signed in Brussels on 17 October 1953 , and legal instruments of the OECD.

The Members of the Forum are: Albania, Armenia, Australia, Austria, Azerbaijan, Belarus, Belgium, Bosnia-Herzegovina, Bulgaria, Canada, Chile, China, Croatia, the Czech Republic, Denmark, Estonia, Finland, France, FYROM, Georgia, Germany, Greece, Hungary, Iceland, India, Ireland, Italy, Japan, Korea, Latvia, Liechtenstein, Lithuania, Luxembourg, Malta, Mexico, Moldova, Montenegro, Netherlands, New Zealand, Norway, Poland, Portugal, Romania, Russia, Serbia, Slovakia, Slovenia, Spain, Sweden, Switzerland, Turkey, Ukraine, the United Kingdom and the United States.

The International Transport Forum's Research Centre gathers statistics and conducts co-operative research programmes addressing all modes of transport. Its findings are widely disseminated and support policymaking in Member countries as well as contributing to the annual summit.

\section{Discussion Papers}

The International Transport Forum's Discussion Paper Series makes economic research, commissioned or carried out at its Research Centre, available to researchers and practitioners. The aim is to contribute to the understanding of the transport sector and to provide inputs to transport policy design. The Discussion Papers are not edited by the International Transport Forum and they reflect the authors' opinions alone.

The Discussion Papers can be downloaded from:

\section{www.internationaltransportforum.org/jtrc/DiscussionPapers/jtrcpapers.html}

The International Transport Forum's website is at: www.internationaltransportforum.org

For further information on the Discussion Papers and other JTRC activities, please email:

\section{itf.contact@oecd.org}

This document and any map included herein are without prejudice to the status of or sovereignty over any territory, to the delimitation of international frontiers and boundaries and to the name of any territory, city or area. 


\section{EXECUTIVE SUMMARY}

This report examines the issue of financing (transportation) infrastructure investment projects. It looks closely at what market failures result in the private sector not being able to cover the investment requirement itself. It then assesses the government failures associated with intervention, and identifies what public-private partnerships (PPPs) offer in overcoming these failures. The limitations of PPPs are then addressed, and the regulated asset base (RAB) model is introduced as a potential alternative, with an assessment of its advantages and disadvantages. The report discusses:

- the economic characteristics of infrastructure;

- market and government failures associated with infrastructure investment;

- benefits and issues associated with PPPs and the RAB model;

- circumstances under which the RAB model may be preferred over PPPs, and vice versa.

The report observes that the up-front, sunk cost profile of infrastructure investment, as well as its long-term nature, leads to market and government failures. Government intervention following private sector provision of infrastructure leads to an inherent problem, namely the time-inconsistency problem. This describes the potential for the government to initially provide a guarantee to investors ensuring recovery of costs associated with the investment, only to renege subsequently and to expropriate rent from the private sector. PPPs and the RAB model both represent a way in which the time-inconsistency problem may be mitigated.

Benefits of PPPs over traditional procurement process arise from (potential) efficiency gains associated with the private sector managing the construction and operation of the infrastructure asset. The main issue concerning the PPP model relates to its inflexibility. This lack of flexibility is necessary in order to mitigate the time-inconsistency problem, but can be a constraint, especially when projects involve very uncertain prospects over the long term. The RAB model overcomes this problem by having a regulator to periodically assess the performance of the private sector provider. However, the RAB model itself has several issues which mean that it does not always represent a superior alternative to PPPs.

- Difficulties in providing an accurate initial RAB valuation.

- Funding - the RAB model does not necessarily resolve the question of who ultimately pays for investments.

- Public procurement-for greenfield projects, the RAB model still requires a method of public procurement.

- Bias towards higher gearing-as in the PPP model, there may be a tendency for assets to be financed with high levels of gearing. This may be considered a concern from a public policy perspective if it results in risk of default that might lead to users being asked to pay more for using the asset. 
- Capital expenditure (CAPEX) bias resulting from the fact that CAPEX is added to the $R A B$ and earns a rate of return over time, whereas operating expenditure (OPEX) is remunerated on a pay-as-you-go basis.

The analysis in this report suggests that the relative advantages of PPPs and the RAB model depend on the specifics of the investment project. Consequently, RAB- and PPP-based approaches provide a broad spectrum of options for encouraging private finance in the transport sector, enabling policymakers to take a 'horses-for-courses' approach. In particular, the report reaches the following conclusions.

- The inherently inflexible nature of PPPs means that when future demand/usage or prices are uncertain, PPPs may prove to be a constricting factor in attempting to maximise social welfare. Under such circumstances, transaction costs are also likely to be large due to the difficulty in assessing contingencies and negotiating consequences. Moreover, the problems with the competitive tender process may also be exacerbated for projects with a high degree of uncertainty. These factors may lead investors to require higher rates of return than otherwise, resulting in excessively high costs of capital for PPP projects.

- Creating a regulator may not be feasible or appropriate in certain situations, especially when the infrastructure investment is not significant. Due to the costs associated with regulation, PPPs may represent a better value-for-money option than the RAB model for relatively small projects (assuming that transaction costs associated with such projects under PPPs are small).

- Past PPPs have exhibited a tendency to attempt to transfer too much risk to the private sector owing to the reluctance of government departments to take on risk. This problem may be mitigated under the RAB model if the regulator can effectively retain its independence from the government.

- Given that even a small saving in the cost of capital can imply a large absolute saving due to the scale of infrastructure investments, it is crucial to evaluate various options, including the RAB model, when financing infrastructure.

- Finally, the overlap between the two methods of financing regarding brown- and greenfield investment suggests that there may be potential for a hybrid approach of PPPs and the RAB model that combines the benefits of both. 


\section{TABLE OF CONTENTS}

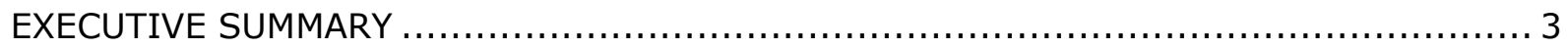

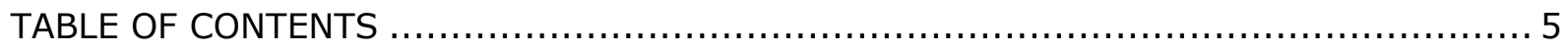

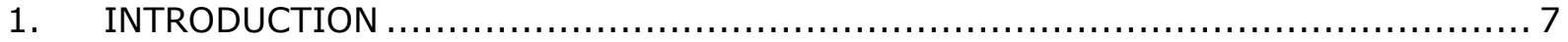

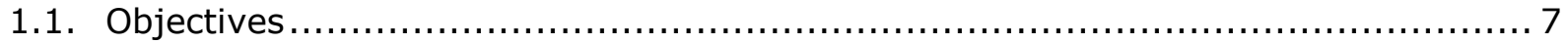

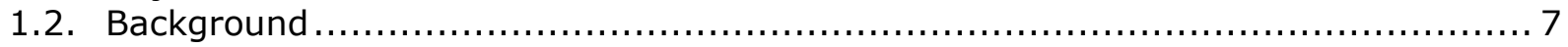

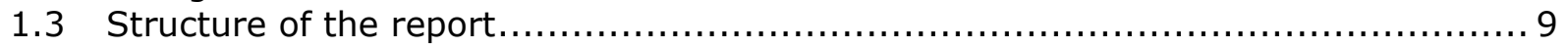

2. WHAT ARE WE TRYING TO DELIVER WITH PUBLIC-PRIVATE PARTNERSHIPS? ...... 10

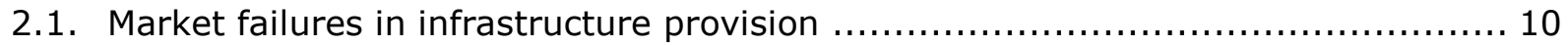

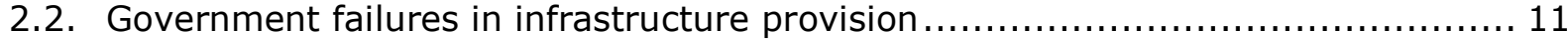

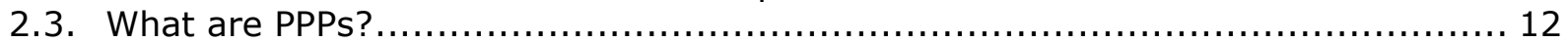

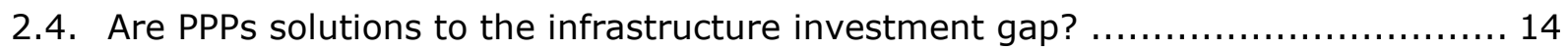

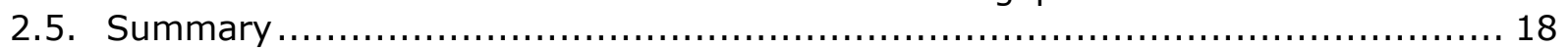

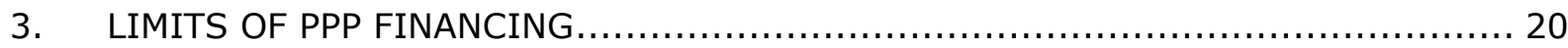

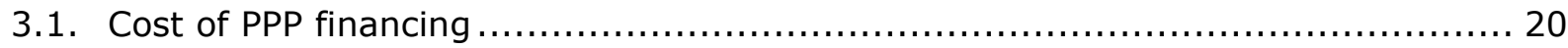

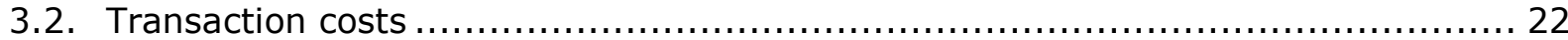

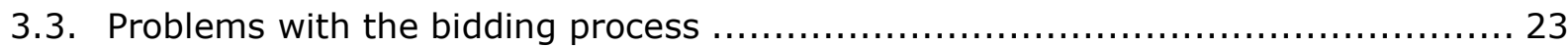

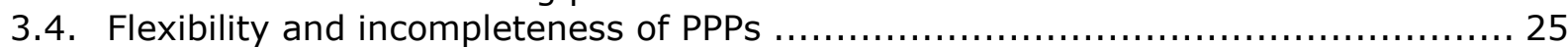

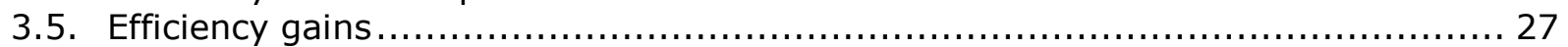

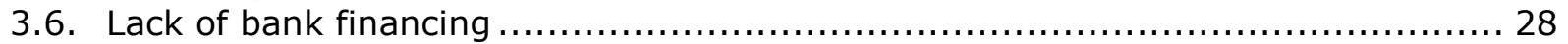

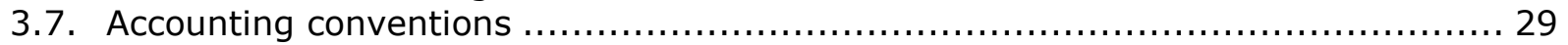

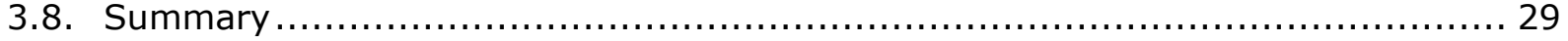

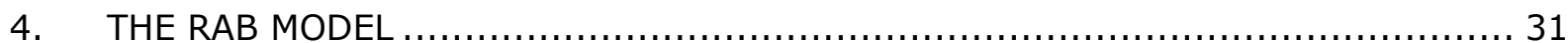

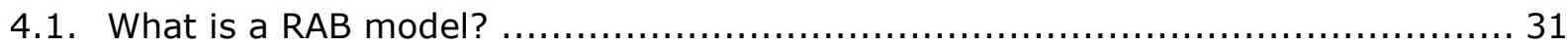

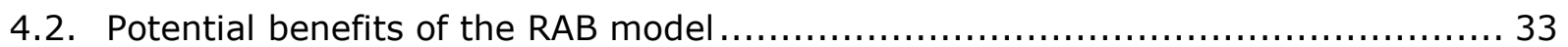

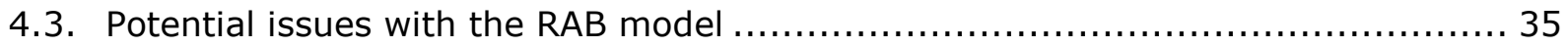

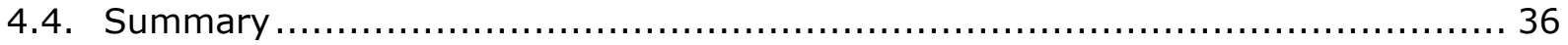

5. WHEN IS THE PPP OR THE RAB MODEL MOST APPLICABLE? ......................... 37

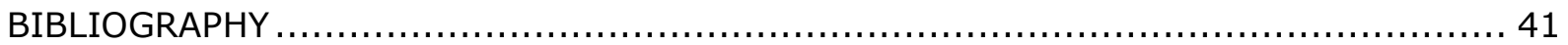





\section{INTRODUCTION}

\subsection{Objectives}

This report examines the issue of financing large-scale infrastructure investment projects. The objectives of the report are to:

- $\quad$ re-examine the conventional wisdom around infrastructure and why there is/is not a funding and/or financing problem;

- provide an assessment of different models for delivering and financing infrastructure; and

- consider the circumstances in which one financing model may be preferred to another-in particular, concentrating on public-private partnerships (PPPs) and the potential for the regulated asset base (RAB) model as an alternative to PPPs for certain investments.

\subsection{Background}

Infrastructure investments are generally associated with significant economic benefits. These benefits can be increases in short-term output and also longer-term growth. For example, of the 21 countries and six types of infrastructure considered in Egert, Araujo and Kozluk (2009), the vast majority of estimated relationships with GDP are found to be positive and to show a return to infrastructure investment over and above that of investment in the capital stock more generally. ${ }^{1}$ This is not surprising given that firm activities are almost always built on underlying infrastructure such as water, electricity, gas and transport. ${ }^{2}$

For these reasons, and together with the fact that there has traditionally been a lack of investment in infrastructure, future infrastructure investment is expected to exceed historical levels by a substantial amount. That is, there is a potentially wide infrastructure 'gap' that will have to be filled in the near future, as the following illustrates.

- Infrastructure UK has estimated that average annual UK investment in infrastructure will need to rise from $£ 30$ billion per annum between 2004 and 2009 to $£ 50$ billion per annum between 2010 and $2030 .^{3}$ The same report estimates that worldwide total investment over $2010-20$ is expected to reach more than $£ 20$ trillion. $^{4}$

1. Egert, B., Araujo, S. and Kozluk, T. (2009), 'Infrastructure and growth: Empirical evidence', OECD Economics Department Working Papers, No.685.

2. For a more specific example, see Oxera (2009), 'What is the contribution of aviation to the UK economy?', final report prepared for Airport Operators Association, November.

3. Infrastructure UK (2010), 'Strategy for National Infrastructure', March, p. 5.

4. Ibid. 
- In the EU alone, the cost of infrastructure development to match demand for transport has been estimated at over $€ 1.5$ trillion for $2010-30$ for the entire transport networks of the Member States. ${ }^{5}$

- The OECD has previously estimated the average annual expenditure requirements in the road and rail sectors by $2030 .{ }^{6}$ In the roads sector, it estimates new infrastructure construction (ie, net additions and maintenance/replacement) over the period 2000 to 2030 at between $\$ 220$ billion and $\$ 290$ billion per year. The report estimates that around two-thirds of all new infrastructure construction in roads is expected to take place in OECD countries, with the majority of this investment requirement arising from the need to maintain, upgrade and replace existing road assets.

- In the rail sector, the report estimates the infrastructure requirement to be between $\$ 50$ billion and $\$ 60$ billion per year over the period $2005-30$. This includes rail upgrading from the EU TEN-T programme and future high-speed rail plans. As in the roads sector, approximately two-thirds of the investment is expected to occur be made in OECD countries.

However, the wider economic benefits of infrastructure can be realised only if projects are approved and receive sufficient financing. This requires that the government is able to issue debt. However, the following constraints on the provision of capital by the public sector might suggest that this is not possible.

- Investor demand-the cost of credit and ability of government to place certain amounts of debt in the market, given investors' demand for government debt.

- Cost of debt-the cost of credit, default risk and the credit rating of the government debt.

- Government/supranational limits-for example, limits on debt and deficit introduced in the EU.

- Long-term fiscal policy-requirement for sustainable levels of debt and deficit in the long term given the target level of indebtedness and projections for tax revenues and expenditure.

As Helm (2009) notes, simply relying on the private sector to provide infrastructure investment is likely to lead to underinvestment due to market failures (market power and externalities):

There are multiple market failures, which together are sufficient to conclude that the private sector, left to its own devices, will produce a seriously sub-optimal level of provision. Put simply, there will be inadequate energy, transport, communications and water networks, to the detriment of consumers and industry. ${ }^{7}$

5. European Commission (2011), 'Proposal for a Regulation of the European Parliament and of the Council establishing the Connecting Europe Facility', October 19th.

6. OECD (2006), 'Infrastructure to 2030: Telecom, Land Transport, Water and Electricity', June 30th.

7. Helm, D. (2009), 'Infrastructure, investment and the economic crisis', published in D. Helm, J. Wardlaw and B. Caldecott (eds), Delivering a 21st Century Infrastructure for Britain, London: Policy Exchange. 
In a bid to overcome these difficulties, governments are seeking private investment in transport infrastructure from 'novel' sources (including sovereign wealth funds, pension funds, and other investors) and governance models. Since the early 1990s, this has often taken the form of PPPs, which have involved long-term contracting between the public and private sector. Under these contracts, the private sector has been required to provide the up-front financing for the infrastructure, and has then received payment from the public sector for providing it with a stream of services.

More recently, there have been calls for alternative models. The RAB adopted in the regulation of utilities in the UK, and subsequently further afield, is one proposed model that has garnered increasing attention. This report considers the market failures that result in the private sector not being able to cover the investment requirement itself. It then assesses the government failures associated with intervention, and identifies what PPPs offer in overcoming these failures. The limitations of the PPPs are then addressed, and the RAB model introduced as a potential alternative, with an assessment of its advantages and disadvantages.

\subsection{Structure of the report}

The structure of the remainder of this report is as follows. Section 2 assesses the market failures which occur in the infrastructure sector that lead to an insufficient source of investment from the private sector, as well as the government failures associated with public sector provision. This section also explains what PPPs are intended to deliver. The observed limitations of PPPs are the subject of section 3. In section 4, the RAB model is introduced and evaluated, and section 5 contains a comparative assessment of the two financing options. 


\section{WHAT ARE WE TRYING TO DELIVER WITH PUBLIC-PRIVATE PARTNERSHIPS?}

The introduction to this report has noted that there is a significant scope and need for future investment in infrastructure, including in the transport sector. In the past, governments have tried numerous ways of funding infrastructure, from full privatisation at one extreme, through partial privatisation, to nationalisation at the other extreme.

This leads to two questions. First, why the market, left on its own, may not deliver socially optimal levels of investment. That is to say, what are the 'market failures' in the infrastructure sector that make it necessary for the public sector to intervene? Second, and conversely, what prevents the public sector from fully closing the investment gap itself? That is, what are the 'government failures' that make it necessary for the private sector to be involved?

This section looks to answer these questions by:

- first, looking to identify the market failures that occur in the infrastructure sector, and that might be expected to lead to an insufficient source of investment from the private sector;

- second, shifting focus on to why state intervention in the sector may lead to government failure;

- third, examining what PPPs are intended to deliver, given the market failures in the infrastructure sector, and the governmental failures of intervention.

\subsection{Market failures in infrastructure provision}

Infrastructure inherently presents the potential for multiple market failures due, to a large extent, to its heavily front-loaded, sunk cost profile and its long-term nature. Its cost profile discourages investments both by incumbents (which fear that their assets could become stranded and their construction costs could run out of control), and by entrants (which, in addition to the stranding and cost control issues, fear that they will not be able to provide services more cheaply than the incumbents). The long-term nature coupled with its monopolistic characteristic implies that demand and regulatory uncertainties are exacerbated, leading to a riskier perception of its cash flows by the investors.

These points are explored in more detail in the following sub-section.

\subsubsection{Market power}

Infrastructure, by its very nature, would constitute a textbook natural monopoly in most cases if left untouched by the government. This is mainly due to the large costs associated with new entry to the market. For example, once an electricity grid is built, it is likely to be uneconomic for another company to build its own grid. In these cases, the monopoly would be able to charge above marginal cost price to its customers. 
While this would enable investors to recover the large initial build costs associated with the infrastructure, which would be impossible in a competitive market, it comes at a cost of underinvestment, relative to the socially optimal amount, and a potential lack of innovation.

Provided that the entry cost is not too large (ie, infrastructure represents a monopoly but not a natural monopoly), it is possible for monopoly rents to induce entry by competitors and the rents to be eroded in the long run. This means that cost recovery by allowing companies to act as a monopoly cannot be an optimal solution.

\subsubsection{Externalities}

Infrastructure has benefits (positive externalities) which may not necessarily be directly captured by the investor; rather, they might be appropriated by users and wider society. For example, while an investor will accrue some revenues from building a toll road, the spillover benefit arising from, say, more reliable commute times for road users may not be realised by the investor, but by the wider society. Thus, in the face of positive externalities, the investor, who is primarily interested in direct benefits, would price the infrastructure investment lower than the wider society. This would lead to socially suboptimal, low levels of investment.

Conversely, for infrastructure that also creates negative externalities (eg, noise, pollution, severance, etc), the investor may be led to finance socially undesirable investment projects.

\subsection{Government failures in infrastructure provision}

\subsubsection{Problems with public provision: Inefficiency}

As a way of overcoming the market failures associated with private sector provision of infrastructure, nationalisation was common during the twentieth century. ${ }^{8}$ Under nationalisation, the private sector may be involved in the construction of infrastructure assets (in the role of contractor), but does not play a part in their operation. This meant that governments had the control and the responsibility to develop the infrastructure assets themselves. This allowed prices to reflect marginal costs, while capital costs could be recovered through general taxation. However, while potentially overcoming market failures, nationalisation was associated with several government failures, including public sector financing constraints, inefficiencies, gold-plating, and a lack of innovation. ${ }^{9}$ For example, Ehrlich et al. (1994) studied productivity and costs of 23 international airlines over the period 1973-83 and indicated that a change from complete state ownership to private ownership would, in the long run, be expected to increase productivity growth by $1.6-2.0 \%$ per annum, while costs would be expected to decline by $1.7-1.9 \%$ per annum. ${ }^{10}$

8. Nationalisation was also a reflection of twentieth century political ideologies, as much as it was a pragmatic way of overcoming market failures.

9. See, for example, Kessides, I. (2005), 'Infrastructure Privatization and Regulation: Promises and Perils', The World Bank Research Observer, 20:1, pp. 82-3.

10. Ehrlich, I., Gallais-Hamonno, G., Liu, Z. and Lutter, R. (1994), 'Productivity Growth and Firm Ownership: An Empirical Investigation', Journal of Political Economy, 102, 1006-38. For a survey of this literature see, for example, Megginson, W.L. and Netter, J.M. (2001), 'From State to Market: A Survey of Empirical Studies on Privatization', Journal of Public Economics, 39, 321-89. 


\subsubsection{Problems with intervention: Time-inconsistency problem}

From a financing perspective, arguably the most prominent government failure in terms of intervening in private sector infrastructure investment stems from its cost profile. Since the proportion of fixed capital costs to total costs is high (that is, infrastructure assets are characterised by high operational gearing), there tends to be a large differential in the levels of average costs and marginal costs.

In fact, infrastructure commonly represents a public good such that, up to the point of congestion, the marginal cost of serving an additional customer is close to zero. This creates a time-inconsistency problem. ${ }^{11}$ The investor needs an ex ante guarantee that it will be able to recover average costs from customers in the long term, but there is an incentive for governments and regulatory bodies-in the knowledge that operation of the asset will continue so long as the operator is able to recover its marginal costs - to intervene to drive prices down to the level of marginal costs ex post. As Helm (2009) notes:

the temptation for politicians and regulators is to promise ex ante that investors who sink capital will be able to recover their investment and the cost of capital. In other words, they will be able to charge average not marginal costs. However, the time inconsistency arises when the investment is complete and the assets are in place. Now the politicians and regulators can force prices to marginal not average costs, and the services continue to be provided. They renege on their ex ante bargain with investors. ${ }^{12}$

The crux of the time-inconsistency problem is that governments need to provide investors with a credible, long-term commitment that they will recover, and earn an adequate rate of return on, their (efficient) investments. Without such a credible commitment mechanism, investors would demand compensation for the political/regulatory risk, leading to a higher cost of financing or worse, lack of funding.

Note that as, by definition, this risk is not within the control of the private sector, its cost should not be borne by the private sector. Indeed, financial theory demands that such exogenous risk be moved to where it is best managed or controlled and, naturally, the government is the most suitable bearer.

\subsection{What are PPPs?}

The potential for market failures in infrastructure calls for government intervention. However, at the same time, the potential for government failure also suggests that state intervention must be undertaken carefully. What is clear is the need for a synergy between the private and the public sectors in building infrastructure.

Public-private partnerships, as the name suggests, aim to provide a means by which such synergy between the two sectors may be achieved in reality. Despite popularity around

11. The time-inconsistency problem is well known from monetary policy. It refers to the potential for the rule-setter (here, government) to behave in an opportunistic manner as its incentives change over time. Specifically, this arises from the fact that what may have been the best solution for the government at one point in time may no longer be the optimal solution at a later point in time, leading it to renege on its past promise.

12. Helm, D. (2009), 'Utility regulation, the RAB and the cost of capital', Competition Commission Spring Lecture 2009, May 6th, p. 3, available at http://www.dieterhelm.co.uk/node/676 
the world, a unanimous definition of PPPs is yet to be agreed ${ }^{13}$ Indeed, there have been almost as many attempts to define PPPs as there have been PPP projects, and there are widespread differences in what the term is taken to encapsulate. The OECD has provided a definition that distinguishes PPPs from more traditional procurement methods on the basis of the amount of risk transferred to the private sector:

One can define a public-private partnership as an agreement between the government and one or more private partners ... according to which the private partners deliver the service in such a manner that the service delivery objectives of the government are aligned with the profit objectives of the private partners and where the effectiveness of the alignment depends on a sufficient transfer of risk to the private partners. ${ }^{14}$

This report follows the OECD definition of the PPP. The major difference between PPPs and traditional public procurement models is that the public sector does not purchase an asset in a PPP; rather it purchases a stream of services under specified terms and conditions. ${ }^{15}$ In other words, the private sector finances and builds the infrastructure, and it retains ownership of the asset at least until the end of the contract (usually around 20-30 years).

Different models fit within the broad PPP concept but, in line with the definition above, the operation of the asset is always the responsibility of the private sector. Each of these models allocates different levels of risk to the private sector. This report is concerned with PPPs in which the role of financing the project falls to the private sector, as the following illustrates.

- Build-Develop-Operate. The private sector party buys or leases an existing asset from a public agency, invests capital to enhance and develop the infrastructure, and then operates it according to the terms of a contract with a public agency.

- Build-Own-Operate. The public agency awards a single contract-which bundles the construction and operation of the infrastructure-to a private entity. The public agency is responsible for specifying the design of the project, but ownership of the asset remains with the private agency once it is built.

- Build-Operate-Transfer. The private entity is responsible for the construction of the infrastructure-according to the design specifications agreed to by the public agency-and subsequently operates the infrastructure for a specified period of time under a contract or franchise agreement with the agency. At the conclusion of the contract, ownership and operation of the infrastructure is transferred to the public agency.

Note that, in the literature, the terms Private Finance Initiative (PFI) and PPP are used interchangeably, although the former was a policy set up by the UK government in 1992. This convention is adopted in this report.

13. Hodge, C.A. and Greve, C. (2007), 'Public-Private Partnerships: An International Performance', Public Administration Review, 67:3, 545-58.

14. OECD (2008), Public-Private Partnerships: In Pursuit of Risk Sharing and Value for Money, OECD Publishing.

15. Grimsey, D. and Lewis, M.K. (2004), Public Private Partnerships: The Worldwide Revolution of Infrastructure Provision and Project Finance, Cheltenham: Edward Elgar, p. 6. 


\subsection{Are PPPs solutions to the infrastructure investment gap?}

The remainder of this section analyses ways in which PPPs may be able to overcome the market and government failures highlighted above. It identifies what governments are trying to deliver, and what potential benefits they are trying to achieve, by introducing private finance instruments. In particular, this relates to overcoming the governmental failures involved in nationalisation and traditional procurement in terms of:

- overcoming the time-inconsistency problem by providing a credible long-term contract;

- targeting private sector efficiencies;

- targeting benefits derived from more efficient risk allocation; and

- overcoming public sector capital constraints, and concerns relating to affordability and intergenerational equity.

These potential benefits are considered in turn.

\subsubsection{Solving the time-consistency problem}

PPPs are governed by contracts that are drawn up between the public agency and the private sector. To the extent that the contract is legally binding and thereby credible, the long-term nature of the PPPs means that they represent a solution to the time-inconsistency problem described in section 2.2.

Without such commitment, investors would require a premium on the rate of return of the project. This would mean that the discount rate would be higher-essentially, the investors would require cost recovery sooner rather than later. This is similar to investment having a front-loaded depreciation profile. PPPs therefore mitigate this problem by providing assurance to investors that they will be able to recover their (sunk) initial cost. This also implies that payments are spread across current and future generations of customers, consistent with the long-lived nature of the assets-ie, promoting intergenerational equity.

\subsubsection{Efficiency}

Nationalisation and rate-of-return regulation have both been criticised on the basis that they lead to operational inefficiencies, and potentially to gold-plating. In terms of nationalisation, Sappington and Stiglitz (1987) state that, if the conditions of an 'ideal setting' are met, the government can always achieve both productive and allocative efficiency by delegating the provision of a good to a private firm through an auction mechanism. ${ }^{16}$ Consequently, public production cannot, in principle, improve upon private production.

PPPs have often built on this expectation that the private sector will be able to provide services more efficiently and more effectively than can the public sector. An objective of PPPs has therefore been to encourage investors to achieve operating cost reductions and to maximise the use of capital expenditure (CAPEX). This can be achieved at several stages in the life cycle of assets, each of which is considered in turn below.

16. An ideal setting constitutes a situation in which there are two or more risk-neutral producers with symmetric belief about the least-cost production technology. See Sappington, D. and Stiglitz, J.E. (1987), 'Privatization, Information and Incentives', Journal of Policy Analysis and Management, 6, pp. 567-82. 
It is important to separate out two key roles that can be played by the private sector in the context of infrastructure assets. First, there is the role played by the private sector in the financing of the infrastructure. Second, there is the role in terms of the ongoing operation of the infrastructure. With regard to efficiency, the benefits of private sector involvement have typically been propagated in the context of the operational management role. The exception to this has been the project selection stage, where it has been suggested that there may be benefits associated with the financing role.

\section{Project selection}

One area that can affect whether infrastructure delivery is efficient is the process by which the decision to carry out the investment project is originally reached. In terms of efficiency, it is important that projects are undertaken where they are net present value(NPV) positive. ${ }^{17}$ In this context, private financing could potentially lead to more efficient decisions being made at the project selection stage.

The public sector may deliver NPV-negative investments if politicians choose to undertake 'vanity' projects, or if there is a general political bias towards the short term (ie, if the politician is likely to be seen in a positive light for getting a project 'off the ground', but may have left office by the time the project runs into any problems). The increased scrutiny of private sector companies and their financiers, which are both putting their money at risk, could in theory ensure that projects are undertaken only if they are likely to perform well. ${ }^{18}$ There could thus be benefits from subjecting potential projects to private sector risk assessment, if the private sector has a comparative advantage in such assessments. This has been noted by Jenkinson (2003):

why have some governments been so keen for public services to raise private finance? Possibly the best argument, although one that is seldom articulated, is that the private sector may be better at evaluating risks than the public sector, and hence the involvement of private finance results in better investment appraisal. ${ }^{19}$

However, this does not appear to have been the case with all projects in practice. Indeed, high-profile PPP failures (eg, Metronet, the M7 Clem Jones Tunnel in Brisbane, Australia, and many more) suggest that private sector appraisal has not helped to ensure that only high-performing projects are undertaken, and that short-termism has also characterised PPPs. ${ }^{20}$

\section{Design and construction}

At the design and construction stage, it is important to find a balance between the project being over- and under-specified. While ensuring that sufficient CAPEX is provided to deliver a network of appropriate quality, well-designed PPPs should be able to strike this balance by:

17. In order for projects to be socially beneficial too, calculation of NPVs must include consideration of external benefits/cost associated with them.

18. Grimsey and Lewis (2004), op. cit.

19. Jenkinson, T. (2003), 'Private Finance', Oxford Review of Economic Policy, 19:2, p. 334.

20. See also Oxera and RBconsult (2012), 'Disincentivising overbidding for toll road concessions', prepared for the Australian Department of Infrastructure and Transport, April. 
- removing incentives to build in additional unnecessary CAPEX or to gold-plate the network;

- creating incentives to minimise the whole life-cycle costs of the infrastructure.

In theory, the private sector is more likely to take the best possible long-term asset stewardship decisions, since it does not face short-term political manipulation. This should result in the minimisation of costs over the whole life cycle of the asset and, in particular, the choice of an appropriate level of up-front CAPEX to keep maintenance costs low in the longer term. Grimsey and Lewis (2004), for example, state that a private firm will have greater incentive 'to plan beyond the bounds of the construction phase and incorporate features that will facilitate operations'.

By contrast, under traditional public sector procurement methods, the contractor-who is involved only in the construction of the infrastructure, and not its operation-has an incentive to minimise capital costs, both to win the contract and to maximise profit relative to a fixed fee contract. This may result in under-spend on construction and, in turn, to inefficiently high maintenance and operation costs in the future. As Parker and Hartley (2003) state:

The private sector becomes responsible for the initial design and construction and operation and maintenance, thereby aligning incentives for low-cost construction with minimising life-time costs of operation. By contrast, capital constrained governments are tempted to lower the construction costs of a publicly financed project at the expense of much higher long-term costs of maintenance and operation. ${ }^{21}$

\section{Operations and maintenance}

Under traditional public sector procurement models, the private sector plays no part in the ongoing operation of the infrastructure. However, PPPs can include provisions for the private sector to undertake an operational management role, as well as a financing role, once the infrastructure has been built. In general, private sector companies are expected to have greater incentives to make cost reductions such that their involvement in operations generates additional operating efficiencies.

This follows from the fact that shareholders-who are the residual claimants of any additional profits resulting from lower costs-are expected to exert pressure on senior management to achieve efficiencies. This profit motive is not commonly mirrored in the public sector where managers do not stand to gain from any profits related to their behaviour. $^{22}$

In spite of these potential efficiencies, Oxera and RBconsult (2012) note that, in practice, governments appear to have been more concerned with minimising their own costs (or maximising their receipts), rather than entering partnerships with private entities that are able to achieve the greatest efficiencies:

21. Parker, D. and Hartley, K. (2003), 'Transaction costs, relational contracting and public private partnerships: a case study of UK defence', Journal of Purchasing \& Supply Management, 9, p. 98

22. Although in some cases, performance-related pay has been introduced to provide senior management with such incentives. 
Once bidders have pre-qualified, their bids have been subject to little scrutiny outside of their demand forecast. It is only after the concession has been awarded to the highest bidder that attention has shifted to attempting to ensure that the asset is operated efficiently (ie, by viewing the asset as part of a network, not as an isolated and insulated, individual project) ${ }^{23}$

Consequently, the actual efficiencies realised in the design, construction and ongoing operation of infrastructure assets may not be as great as might be predicted. This is considered further in section 3.5.

\subsubsection{Optimal risk allocation and pricing}

Recalling the definition of PPPs set out by the OECD, risk and who bears it are important factors when considering PPPs. ${ }^{24}$ Risks regarding infrastructure may be divided into two types: commercial and political risk. It is generally assumed that the private sector is better suited to managing commercial risk, while the public sector is more suited to controlling political risk.

Under PPPs, the private sector assumes control of commercial risk. Since commercial risks are endogenous and under the company's control, this leads to technical efficiency. Hence, risk allocation in this way can be seen to be an improvement over simple public provision. However, such risk allocation can be achieved even with traditional public procurements. What PPPs bring is the ability to pass on other risks: demand risk and other risk specific to the private sector party. To the extent that the private sector is able to manage these more effectively than the government, this could potentially lead to additional efficiencies.

It is sometimes thought that, because the government can fund projects more cheaply than the private sector (since it has its taxpayers to fall back on), public sector provision involves less risk. This is a misconception. The transfer of risk from the government to the private sector does not involve reductions in the aggregated risk. The latter remains constant with the transfer. The difference in perceived riskiness suggested by the difference in financing costs arises because the risk of the project is priced explicitly when conducted by the private sector, whereas it can to some extent be masked with public sector provision.

By making project risk explicit, PPPs can, if designed appropriately, bring to light the true riskiness of the project, which may have been disguised under public provision. ${ }^{25}$ Specifically, under public provision, the cost of capital would consist of remuneration for only (government) debt risk, while the equity risk of the project would be masked by the government's vast portfolio. When the private sector attempts to finance the project, on the other hand, the equity risk would be priced into the cost of capital. The question remains as to whether risk can be priced accurately, but the improved transparency in the true cost of capital for the project is a benefit if it is then accounted for in decisions over which projects are selected by government for funding across the board, both with public funds and under PPPs.

23. Oxera and RBconsult (2012), op. cit., p. 12.

24. This report does not make the distinction between risk and uncertainty, where the former involves known probabilities of contingent events, and the latter is an issue of unknown probabilities.

25. Oxera and RBconsult (2012), op. cit. 


\subsubsection{Affordability.}

The financing problem is in large part a short-term 'affordability' problem combined with heightened uncertainty about long-term demand. By using private sector financing, rather than traditional government debt funding, governments have not been required to make upfront payments for projects that have been undertaken by the private sector. This has helped them to overcome two constraints.

- Cash constraints-since governments have not been required to provide up-front payments, they have not needed to find short-term cash flows to fund the project.

- Budgetary constraints-a key objective of PFIs has been to get capital investments off the government balance sheets due to fiscal rules or budgetary limits. Under PPPs and PFIs, the financing for the infrastructure comes from the private sector so, as Grout (1997) explains, 'the investment may be provided without affecting the public sector borrowing requirement (PSBR), even though the present value of the financial commitment by the government may be very similar whether the public sector owns the asset or not. ${ }^{26}$

In countries with commitments to fiscal rules (eg, EU government under the Stability Growth Pact), the latter constraint has created a strong political attraction for private finance incentives. This was previously the case in the UK, for example, where the Labour government introduced requirements for overall fiscal balance (ie, government budget must be balanced) and for public sector net debt to not exceed $40 \%$ of GDP over the economic cycle.

However, the fact that the project cost is not included in the PSBR does not make it affordable. OECD (2008) defines a project to be affordable 'if government expenditure associated with a project, be it a PPP or other mode of delivery, can be accommodated within the inter-temporal budget constraint on the government ${ }^{\prime 27}$ Reducing the requirement for the public sector to make up-front payments may make a project more affordable, but this is not necessarily the case, since it may not affect the present value of the liability. Instead, the payment of the fees by the government may merely be pushed back to a later date. Therefore, concerns about budgetary constraints ought not to be the reason for pursuing PPPs over traditional procurement methods.

\subsection{Summary}

This section has identified the market failures that prevail in the provision of infrastructure as well as the potential government failures from complete state provision or intervention. Most notably, it has been argued that the private sector, without credible commitment by the government on its cost recovery, will deliver a sub-optimal level of investment due to the time-inconsistency problem. The greater the mismatch between the profile of costs and the profile of cost recovery, the greater the time-inconsistency problem, and the greater the risk to the investor.

26. Grout, P.A. (1997), 'The Economics of the Private Finance Initiative', Oxford Review of Economic Policy, 13:4, p. 54.

27. OECD (2008), Public-Private Partnerships: In Pursuit of Risk Sharing and Value for Money, OECD Publishing, p. 36. 
New private finance instruments have been introduced as a means of overcoming the time-inconsistency problem, while trying to capitalise on the potential efficiencies of private sector participation. This includes efficiencies related to:

- explicit pricing of risk;

- any private sector comparative advantage in risk assessment;

- ongoing operational and maintenance efficiencies;

- greater likelihood of entrepreneurial and innovative processes; and

- the transfer of risk to the private sector in instances where it can manage it more effectively.

It should be noted that the use of PPPs should not be driven by any desire on the government's part to remove future liabilities from the balance sheet.

Despite these targeted benefits, problems with PPPs have been extensively discussed in the literature (and, indeed, the extent to which efficiency benefits have been realised has been one point of contention). Moreover, there have been some high-profile PPP failures that have garnered considerable media and political attention. An insight into the circumstances in which PPPs seem less successful is provided in the next section. 


\section{LIMITS OF PPP FINANCING}

The use of PPPs to replace or complement the public provision of infrastructure has become common in recent years, as governments have looked to reduce government borrowing and capitalise on perceived efficiencies of private enterprise. Blanc-Brude, Goldsmith and Välilä (2007) report that in Europe alone, more than 1000 long-term, infrastructure PPP contracts were signed between 1990 and 2006, with a capital value in excess of $€ 200$ billion. ${ }^{28}$ At the forefront of this has been the UK, which, in the form of PFIs, accounted for $76 \%$ of the PPPs signed by European countries over this period ( $57 \%$ by value)..$^{29}$ However, PPPs have also been increasingly prevalent in Australia and continental Europe (notably France, Spain, Portugal, Italy and Germany).

Despite the popularity of PPPs, their effectiveness compared with traditional procurement is yet to be determined. Indeed there have been some high-profile PPP failures. Recent examples include the default of Metronet, which was responsible for the maintenance, renewal and upgrade of nine lines on the London Underground; ${ }^{30}$ the significant cost overruns for the Edinburgh trams project; and the legal and financial difficulties facing the M7 Clem Jones Tunnel in Brisbane, Australia. ${ }^{31}$

The remainder of this section focuses on the limits of PPP financing, focusing on the circumstances under which PPPs may not be appropriate.

\subsection{Cost of PPP financing}

One of the perennial objections to PPPs is that private sector financing costs are higher than the government's cost of debt, and hence PPPs are more expensive to finance than traditional public procurement. ${ }^{32}$ Thus, the argument goes, PPPs will deliver overall cost benefits only where the private sector is able to generate substantial efficiencies in operations. For example, Parker and Hartley (2003) state that:

28. Blanc-Brude, F., Goldsmith, H. and Välilä, T. (2008), 'Public Private Partnerships in Europe: An Update', European Investment Bank, Economic \& Financial Report 2007/03, Economic and Financial Studies, Luxembourg.

29. ibid, p. 8.

30. For discussion of the issues surrounding Metronet, see National Audit Office (2009), 'The Department for Transport: The failure of Metronet', report by the Comptroller and Auditor General, HC 512 Session 2008-09, June 5th.

31. Oxera and RBconsult (2012), op. cit.

32. Grimsey, D. and Lewis, M. (2007), 'Public private partnerships and public procurement', Agenda, $14: 2$, pp. $171-88$. 
Governments can always borrow more cheaply than the private sector. For PPPs to produce overall cost savings, therefore, the extra financing cost (estimated at between one and three percentage points in the UK) needs to be offset by savings in other aspects of the project achieved by the private sector. ${ }^{33}$

This argument has been echoed by numerous academics and, indeed, governments. The UK House of Commons Treasury Committee, for example, recently argued that 'government has always been able to obtain cheaper funding than private providers of project finance' and that the cost of capital of PPPs was currently double that of government gilts. ${ }^{34}$

However, Grout (1997) and Jenkinson (2003) argue that, in theory, private sector borrowing costs should not always be higher than public sector costs, where the latter are properly calculated. ${ }^{35}$ This builds on Modigliani and Miller's proposition that the overall cost of capital is invariant to the method of financing, including whether it is funded by public or private finance. What does determine the cost of capital is the overall underlying risk of the project. While this risk is captured in the returns required by the private sector, it is not captured in the government's cost of borrowing as measured by real interest rates on government debt.

There is always equity in any financing structure although it is not always easy to spot it. In the case where finance is provided via the public sector, the equity is essentially provided by taxpayers in general and/or the customer ... debt raised on the back of a government guarantee is, in the case of major economies, essentially risk free and non-hypothecated: governments will not refuse to pay the interest and principle if a particular public service cannot cover its costs. The only remaining ways of absorbing such risks are to inject funds from general taxation and/or increase user charges. In either case, the risks that cause the loss are real and are being borne by some, or all, taxpayers. ${ }^{36}$

The argument that public sector finance is cheaper because government borrowing costs are lower than the private sector cost of capital has thus been challenged, on the basis that it does not account for the (equity) risks borne by taxpayers. Specifically, equity risk is borne by taxpayers in the sense that if the publicly provided service does not cover its costs, the gap will be funded through higher charges or the use of general taxes. However, that is not to say the costs of public and private finance are the same in all instances. As Jenkinson (2003) acknowledges, the costs of financing a particular project will be the same for public and private finance only if 'contracts are easy to define, risks are well understood, transaction costs are low, and competition to provide finance is active'.

Under certain situations, however, it may be the case that the cost of financing under PPPs is higher than under public provision. For example, misallocating risks associated with various aspects of the project may lead to a higher cost of capital under PPPs relative to public provision.

33. Parker and Hartley (2003), op. cit., pp. 98-99.

34. House of Commons Treasury Committee (2011). 'Private Finance Initiative', Seventeenth Report of Session 2010-12, July 11 th, p. 18, para 30.

35. Grout, P.A. (1997), 'The Economics of the Private Finance Initiative', Oxford Review of Economic Policy, 13:4, 53-66; Jenkinson, T. (2003), 'Private Finance', Oxford Review of Economic Policy, $19: 2,323-34$.

36. Jenkinson (2003), op. cit., p. 325. 
This relates to the fundamental idea in financial theory that risks should be transferred to the party that is best able to manage it. Hence, if too much risk is passed on to the private sector via PPPs, investors would require a higher return in order to compensate for it.

Indeed, a feature of PPP contracts in practice has been that the public sector has looked to push as much risk as possible on to the private sector, regardless of which party is best able to manage that risk. ${ }^{37}$ This has seemingly stemmed from a reluctance within some public agencies to take on risks/costs, even where they have been best placed to do so. The effect of inappropriately passing risk to the private sector is that it pushes up the cost of capital, and hence the overall cost of the project.

In the UK, the Treasury Select Committee has highlighted the negative impact this has had on PPP outcomes.

Allocating risk to the private sector is only worthwhile if it is better able to manage the risk and can pass on any subsequent savings to the client ... We have seen evidence that PFI has not provided good value from risk transfer-in some cases inappropriate risks have been given to the private sector to manage. This has resulted in higher prices and has been inefficient. ${ }^{38}$

Hence, although there is nothing in theory per se that would imply a higher cost of financing for private sector provision of infrastructure investment, inappropriate allocation of risk and many other factors (some of which are discussed below) may mean a higher cost of capital when investment is undertaken by the private sector relative to the public sector.

\subsection{Transaction costs}

One means of overcoming the problems created by uncertainty around future outcomes is to build other outcome-dependent terms and risk-sharing mechanisms into the contracts. However, this can make the contract increasingly complex and has led to the criticism that the transaction costs associated with PPP contracts (including costs of specification, tendering and agreeing contracts) have been high.

Microeconomic theory was historically dominated by the paradigm that markets contained perfect information and that there was no cost involved in completing transactions. Coase (1960), disproving the latter assumption, explained that transactions are not, in fact, costless:

in order to carry out a market transaction it is necessary to discover who it is that one wishes to deal with, to inform people that one wishes to deal and on what terms, to conduct negotiations leading up to a bargain, to draw up a contract, to undertake the inspection needed to make sure that the terms of the contract are being observed, and so on. ${ }^{39}$

Typically, there are considered to be three main categories of transaction cost.

37. See, for example, Gao and Handley-Schachler (2004), 'Public bodies' perceptions on risk transfer in the UK's PPP', Journal of Finance and Management in Public Services, 3:1, pp. 25-39; Ng, A. and Loosemore, M. (2007), 'Risk allocation in the private provision of public infrastructure', International Journal of Project Management, 25, pp. 66-76.

38. House of Commons Treasury Committee (2011), op. cit., p. 21, para 38.

39. Coase, R.H. (1960), 'The Problem of Social Cost', The Journal of Law and Economics, 3, p. 15. 
- Search and information costs-those costs associated with finding a private sector company (or consortium) capable of supplying or operating the infrastructure as required by the public sector. This will also include bidding costs for the private sector companies.

- Negotiation costs - those costs related to agreeing the terms and conditions of a contract, including the structure of payments, the transfer of risk, and other detailed project specifications.

- Monitoring and enforcement costs-once the contract has been signed, and the private sector has commenced construction or operations, the public sector needs to ensure that the private sector is delivering against its promises.

Related to transaction costs is the additional criticism that PPP procurement processes have been drawn out, creating long lead times from project selection to inception. ${ }^{40}$ Grimsey and Lewis (2007) suggest that procurement for PPP projects has taken an average of 12-18 months in Australia, and around 22 months in the UK, and note that:

It takes a long time to agree the risk transfers, payments and terms that are acceptable to both parties-imposing considerable legal and due diligence costs on both the contractors and public sector side. ${ }^{41}$

As an example, the costs of the five-year procurement process for the London Underground PPP contract were estimated at $£ 455 \mathrm{~m} .{ }^{42}$ London Underground itself spent $£ 180 \mathrm{~m}$ during contracting, covering expenditure on legal, engineering and operational advice. Bidders' costs, including those of unsuccessful bidders, equaled $£ 275 \mathrm{~m}$. However, what arguably matters is the size of these costs relative to the total costs (and benefits) incurred over the lifetime of the PPP. The $£ 455 \mathrm{~m}$ transactions costs of the London Underground PPP represented $2.8 \%$ of the NPV of the deal. ${ }^{43}$

The relative transaction costs of tendering for the London Underground PPP contract appear to be fairly typical of PPP contracts in general. A report by the Adam Smith institute in 1996 found that the total cost of tendering for PPP projects, when all potential contractors (ie, winning and losing bidders) were considered, was just under $3 \%$ of total expected project costs. In comparison, the corresponding figure for conventional procurement was lower, at around $1 \% .^{44}$

\subsection{Problems with the bidding process}

PPPs have failed to overcome some of the problems of bidding that are associated with traditional procurement methods. In particular, a criticism of transport infrastructure projects has been that private sector companies have systematically underestimated the

40. This has been used to argue that PPPs are inappropriate for small-scale projects.

41. Grimsey and Lewis (2007), op. cit., p. 181.

42. http://www.publications.parliament.uk/pa/cm200405/cmselect/cmpubacc/446/446.pdf.

43. House of Commons Committee of Public Accounts (2005), 'London Underground Public Private Partnerships', March 9th, p. 14.

44. Butler, E. and Stewart, A. (1996), 'Seize the Initiative', Adam Smith Institute quoted in House of Commons Economic Policy and Statistics Section (2003), 'The Private Finance Initiative (PFI)', Research paper 03/79, October 21st, p. 34. 
costs that will be involved in delivering these projects, ${ }^{45}$ or overestimated the demand for the finished product. ${ }^{46}$ In PPPs, this has led to overbidding in the form of inflated traffic and revenue forecasts ${ }^{47}$ As noted in Oxera and RBconsult (2012), examples of overestimated demand forecasts are prevalent in studies on toll road PPPs.

- Baeza and Vassallo (2008) found that, for a sample of 14 Spanish toll roads, annual traffic was, on average, $35 \%$ below forecast in the first year of operations; $31 \%$ below forecast in the second year; and $27 \%$ below forecast in the third year. ${ }^{48}$ The authors conclude that there is 'a clear bias towards overestimation of traffic in the ramp-up period for toll motorway concessions in Spain'.

- Bain (2009) analysed the ratios of actual traffic numbers to those forecast in more than 100 road, bridge and tunnel concessions. Ratios smaller than 1.0 suggest an overestimation in the forecast numbers. Bain found that the observed ratios ranged between 0.14 and 1.51 (ie, from actual traffic being only $14 \%$ of the forecast to actual traffic exceeding the forecast by $51 \%$ ), with a mean of 0.77 . These results are indicative of a systematic tendency to overestimate traffic forecasts, with actual traffic volumes $23 \%$ below the forecast levels, on average.

- A study of Australian toll roads undertaken by Li and Hensher (2010) found that actual traffic volumes using five facilities (the M2, M7, Cross City Tunnel, Lane Cove Tunnel and EastLink) were $45 \%$ below forecast in the first operational year, and, despite the gap reducing over time, remained $19 \%$ lower than forecast after six years. ${ }^{49}$

On the one hand, overbidding can be to the benefit of taxpayers in the short term, as the government raises greater premium payments (or is required to grant a smaller subsidy)..$^{50}$ On the other hand, it can lead to underinvestment, financial distress-and potentially even default-and could dampen enthusiasm for subsequent involvement in the industry. ${ }^{51}$ Defaulting operators can impose high costs on the government in terms of:

- the direct costs of terminating the contract;

- the costs of re-tendering the project and assessing bid submissions;

45. See, for example, Pickrell, D.H. (1990), 'Urban rail transit projects: Forecast versus actual ridership and cost', US Department of Transportation; Flyvbjerg, B. Holm, M.S. and Buhl, S. (2002), 'Underestimating Costs in Public Works Projects-Error or Lie', Journal of the American Planning Association, 68:3, pp. 279-95.

46. Flyvbjerg, B. Holm, M.S. and Buhl, S. (2005), 'How (in)accurate are demand forecasts in public works projects? The case of transportation', Journal of the American Planning Association, 71:2, 1, pp. 31-46; Bain, R. (2009), 'Error and Optimism Bias in Toll Road Traffic Forecasts', Transportation, 36: 5, pp. 469-82.

47. Oxera and RBconsult (2012), op. cit.

48. Baeza, M.A. and Vassallo, J.M. (2008), 'Traffic Uncertainty in Toll Motorway Concessions in Spain: an Analysis of the Ramp-up Period', TRANSyT working paper, 2008-01, pp. 1-18.

49. Li, Z. and Hensher, A. (2010), 'Toll Roads in Australia: An Overview of Characteristics and Accuracy of Demand Forecasts', Transport Reviews, 30:5.

50. Although there may be less benefit for end-users if high bids reflect high charges for the use of the infrastructure.

51. The latter has been observed in other industries, where investors have responded to previous failings stemming from overbidding by withdrawing from the industry. 
- the costs of stepping in as the 'operator of last resort'; and

- forgone revenues from the defaulting party.

Overbidding can also have less obvious costs. One of the intentions of competitive tendering for PPP contracts is that it should ensure that each PPP is awarded to the private sector party that can carry out the contracted functions most efficiently. However, overbidding could discourage well-qualified (and perhaps better-qualified) parties from entering the bidding process-because they understand that they will win the contract only if they pay over the odds-and could thus be particularly damaging from an efficiency perspective.

\subsection{Flexibility and incompleteness of PPPs}

PPPs are partly designed to mitigate the time-inconsistency problem inherent in infrastructure investment. This necessarily means that contracts between the private and the public sectors must be sufficiently concrete and well-specified to deter each party from behaving in an opportunistic manner. The unwanted consequence of this is that PPPs tend to be inflexible.

The lack of flexibility may be a problem if terms under initial contracts are mis-specified, which is likely in the case where future demand is highly uncertain. For example, the inflexibility of PPPs might not allow the parties to take into account exogenous, unexpected cost shocks. As argued earlier, however, PPPs needs to be sufficiently concrete to mitigate the time-inconsistency problem. Thus, a successful PPP must provide a good balance between adequate flexibility following an unexpected, exogenous event while ensuring sufficient investor protection.

Another concern for PPPs is derived from the fact that the contracting takes place with inherent uncertainty about future market and macroeconomic conditions. This means that PPP contracts do not specify what actions are to be taken and the resulting consequences in all possible future contingencies-ie, PPPs are examples of incomplete contracts. This problem is magnified by long duration and infrastructure-specific issues (eg, greenfield volume risk). ${ }^{52}$ As Parker and Hartley (2003) explain, contract incompleteness may lead to opportunistic behaviour that is harmful to the PPP:

Where buyers and suppliers have imperfect and asymmetric information when contracting, contracts cannot be optimal in a full information sense. It is difficult to write complete contingent claims contracts (allowing for uncertain events) especially where contracts cover a lengthy period of time, technologies and costs are inherently uncertain or the economic environment is in a state of flux. [Moreover,] imperfect information enables parties to a contract to operate opportunistically exploiting any information asymmetry. ${ }^{53}$

Note that either the government or the private sector side may behave opportunistically.

On the government side, this could take the form of post-contract exploitation of the private partner. Hence, if PPP contracts are not well-specified, PPPs would not adequately overcome the time-inconsistency problem.

52. Parker and Hartley (2003), op. cit.

53. Ibid, p. 99. 
The incompleteness of contracts can therefore create a high degree of uncertainty and greater risk in PPPs, which can in turn push up the cost of capital.

For the private sector, the scope for opportunism is related to the specificity of the infrastructure assets provided. ${ }^{54}$ If the assets have been constructed and operated using investments, technologies and procedures which are specific to the incumbent, the value of the assets would be diminished were that company to be replaced. This creates a 'lock-in' effect with the public authority unable to switch to another operator without incurring considerable costs. Insofar as the incumbent is aware of this lock-in, it will have incentives to behave opportunistically by, for example, strategically investing in non-transferable assets. A second opportunistic action the private sector can take is to take on an excessive level of debt and increase the risk of financial distress. The incumbent may then look to renegotiate the terms of the contract so as to make them more favourable, with higher user charges or a lower investment requirement).

Guasch (2004) studied a dataset of more than 1,000 concessions granted in the Latin American and Caribbean region during the period $1985-2000 .{ }^{55}$ Renegotiation of the initial contract was found to have occurred in $55 \%$ of transportation concessions, an average of three years after their reward. The majority of these renegotiations were made at the request of the private contractor and typically involved an increase in tariffs (62\% of cases), delays in investment obligations ( $69 \%$ of cases), and a reduction in the fee paid by the contractor to the public sector ( $31 \%$ of cases).

Although renegotiation can enhance welfare where it helps to address incomplete contracts, the ability of firms to renegotiate in this manner after the contract has been awarded-and, in doing so, to secure more favourable outcomes for themselves-can exacerbate the problems at the bidding stage. ${ }^{56}$ Unless companies feel that their bids represent an actual commitment to deliver the stated outcomes, they could have an incentive to push their bids up, on the basis that they can later be revised down. ${ }^{57}$ This reduces the likelihood that competitive bidding will ensure that the most efficient bidder is awarded the contract.

One means of overcoming this would be to include up front, in the initial contract agreement, framework parameters to allow subsequent renegotiation of contracts. Such a framework could cover the grounds for initiating renegotiation, preferred mechanisms for adjusting contracts (eg, concession extension, increased tolls, reduced investments, etc), and so on. This could act to ensure that there is flexibility to change the contract in the event that there is a change in the business environment, while limiting the potential for the incumbent to hold the government to ransom. However, as noted in section 3.2, this could lead to increasingly complex contracts and thus excessively high transaction costs, which could limit any potential benefits.

54. These arguments were first put forward by Oliver Williamson. See, for example, Williamson, O. (1975), Market and Hierarchies: Analysis and Antitrust Implications, Free Press; Williamson, O. (1976), 'Franchise Bidding: In General and with Respect to CATV', Bell Journal of Economics, 7:1, pp. 73-104.

55. Guasch, J.L. (2004), 'Granting and Renegotiating Infrastructure Concessions-Doing it Right', World Bank Institute Development Studies, 28816.

56. Oxera and RBconsult (2012), op. cit.

57. For example, Baeza and Vassallo (2008), op. cit., find that the willingness of the Spanish government to renegotiate concession contracts has encouraged aggressive bidding and traffic overestimations. 
This approach is also unlikely to provide sufficient flexibility to deal with unforeseen circumstances, without creating some scope for opportunism.

The inflexible and incomplete nature of PPPs implies that they may not be appropriate for all types of infrastructure investment. Particularly for investments that are unprecedented-and thus which typically involve highly uncertain revenue and growth prospects-PPPs may be superseded by other forms of procurement. For example, Oxera (2011) sets out a co-investment model for telecoms next-generation access (NGA) investment. ${ }^{58}$ This is due to the inherent risky nature of the investment where there is still no consensus on exactly which technology would best replace the legacy infrastructure.

\subsection{Efficiency gains}

One of the motives behind PPPs has been to capture the profit-maximising motive of the private sector in order to drive technical efficiency. However, not all PPPs have been conducted with the secure knowledge that the private sector will be more efficient than the public sector. For example, when the UK began its PPP initiative-the Private Finance Initiative (PFI)-lack of interest in PPPs from the private sector meant that the government was forced to make the scheme more attractive, which ultimately led to the abolition of universal testing of projects for private finance. In 1992, rules relating to the use of private funds by the public sector were revised such that privately financed projects would be allowed to go ahead without any need to compare them with a similar project in the public sector.

Given this government stance, the desired efficiency gain from private sector involvement may not be realised if it is the case that PPPs were used inappropriately. Despite this potential overuse of PPPs by the government, Hodge (2004) argues that the UK government departments that implemented PPPs registered cost savings of between $10 \%$ and $20 \% .{ }^{59}$ Other experiences of PPPs have been generally positive. ${ }^{60}$ However, the literature is inconclusive on the effectiveness of PPPs-eg, Gaffney and Pollock (1999) found that PFIs had not led to overall cost savings in the National Health Service in the UK. ${ }^{61}$

The assumption that private sector operations will generate efficiencies (that the public sector will not) builds from the fact that private sector companies have a profit motive-that is, equity holders are the residual claimants of any additional profits which are achieved by becoming more efficient. However, debt and equity holders may have different financial incentives, regarding whether they are primarily motivated to increase the 'gain' or to minimise the potential for 'loss'. Equity holders would be expected to have an incentive to achieve performance greater than that expected when the contract is signed. However, creditors may be motivated to avoid downside risks. Since PPPs have tended to be highly geared (frequently greater than $90 \%$ gearing), equity incentives may not be as strong as anticipated, leading to fewer incentives to achieve private sector efficiencies.

58. NGA investment concerns provision of, for example, fibre optic-cables to allow faster broadband access. See Oxera (2011), 'How a co-investment model could boost investments in NGA networks: Feasibility and implementation of a co-investment model', prepared for Vodafone, November.

59. Hodge, G.A. (2004), 'The Risky Business of Public-Private Partnerships', Australian Journal of Public Administration, 63:4, pp. 37-49.

60. See, for example, Hodge, G. And Greve, C. (2009), 'PPPs: The Passage of Time Permits a Sober Reflection', Economic Affairs, 29:1, pp. 33-39.

61. Gaffney, D. and Pollock, A.M. (1999), 'Pump-Priming the PFI: Why are Privately Finance Hospital Schemes Being Subsidized', Public Money and Management, 19:1, p. 62. 
The highly geared nature of PPPs also gives the private sector bargaining power over the government, especially for mission-critical infrastructure. Specifically, a high level of debt would imply greater financial risk, but this could be passed on to the government if it is 'known' that the government would not let the company go bankrupt. This occurs when the government's cost of guaranteeing a company is lower than the cost of allowing it to go bankrupt.

\subsection{Lack of bank financing}

In the UK, PPPs have typically been bond-financed. Outside of the UK, however, PPPS have tended to be reliant on bank financing, with limited access to capital markets. A report by the European Investment Bank attributes this to a number of factors:

lack of a deep capital market, resulting in illiquidity in the asset; lack of a large private pension system, resulting in insufficient demand for the asset; a strong local banking market willing to maintain market share through aggressive pricing and terms; and insufficient knowledge of the bond market on the part of both the public sector and private sponsors leading to the perception that the bond execution is 'difficult'. ${ }^{62}$

Moreover, where European PPPs have been bond-financed, the large majority of bonds have been issued with monoline guarantees. The role of the monolines has been to issue guarantees on the repayment of the principal and interest to investors. ${ }^{63}$ The issuer of the bond has then been able to benefit from the high credit rating of the monoline (which would maintain a sufficient capital base against the guarantees to secure a triple-A rating) rather than its own rating. This has had the result of lowering financing costs. However, following the financial crisis there has been a widespread downgrading of the monolines, with serious implications for the PPP bond market in Europe.

The demise of the monoline insurers has, to all intents and purposes, seen the closure of the wrapped bond market, and there has yet to be a viable, alternative means of tapping into the capital market. ${ }^{64}$ The onus on bank financing for PPPs is thus stronger than ever. However, the current problems in the banking sector are well reported:

the collapse of the inter-bank lending market has drastically reduced liquidity. Most banks, particularly those with limited deposit bases, are struggling to raise funds even on short maturities ... Project finance and PPP lending is competing for scarce regulatory capital allocations with more attractive corporate opportunities. This is testing the viability of the current PPP model. ${ }^{65}$

Going forward there remains a question of how banking sector reforms, introduced in response to the financial crisis, will affect the existing stock of infrastructure loans and banks' capacity to supply financing.

62. European PPP Expertise Centre (2010), 'Capital markets in PPP financing: Where we were and where are we going', March, p. 5, para.1.1.2.

63. Ibid.

64. Ibid. For example, 'following the downgrading of the monolines' ratings, bond investors have withdrawn from the PPP market.' (p. 15)

65. European PPP Expertise Centre (2009), 'The financial crisis and the PPP market: Potential Remedial Actions', August, p. 5. 


\subsection{Accounting conventions}

It should not be ignored that a significant amount of the enthusiasm for PPPs (at least in the UK) arose from an accounting convention that meant that the future liability to pay the private sector did not enter the government's balance sheet/public expenditure. It is a problem if the government believes in the 'free-money fallacy' of PPPs and that it could spend the money 'saved' by using PPPs on something else. PPPs, by design, mean that the government purchases services from the private sector. However, the price the government pays will be higher (ie, above marginal cost) in order for the private sector to recover the large sunk cost. In other words, financing infrastructure via PPPs is likely to cost just as much as if the government pursued a more traditional procurement method.

In the UK, the Office for Budget Responsibility has estimated that national debt would be increased by $£ 35$ billion (2.5\% of GDP) if all current PPP liabilities were included in the national accounts. ${ }^{66}$ Recently, however, the political incentives to target off-balance-sheet financing appear to have been reduced, for two reasons.

- Under the International Financial Reporting Standards (IFRS), which have become increasingly recognised over recent years, all PPP debt must be included in public sector authorities' financial accounts for financial reporting purposes. ${ }^{67}$

- The liability on future generations from PPP contracting has come to the fore, as payments for the PPPs have begun to be made from current budgets. In turn, politicians have recognised that the apparent 'free money' of PPP projects was not actually free at all.

\subsection{Summary}

This section has shown that PPPs may not always be the most appropriate solution to the challenge of infrastructure investment. Indeed, under certain circumstances, PPPs may be superseded by other methods of financing. This has led some governments to look for alternatives to PPPs. Even the UK government, historically the biggest proponent of PPP projects, has acknowledged the potential need for such alternatives:

the Government shares some of the commonly identified concerns that PFI contracts can be too costly, inflexible and opaque ... The Government now intends to undertake a fundamental reassessment of PFI and wants to develop a new delivery model that draws on private sector innovation but at a lower cost to the taxpayer and offering better value for our investment in public services. ${ }^{68}$

This has been the result of a number of contributing factors, including:

- high transaction costs;

- inherent inflexibility and incompleteness of contracts and payments;

- limits to cross-fertilisation of ideas across the public sector;

- private sector opportunism, inflated demand forecasts and forced renegotiations;

66. Office for Budget Responsibility (2011), 'Fiscal sustainability report', July, p. 79.

67. Parker, D. (2012), 'The Private Finance Initiative and Intergenerational Equity', on behalf of The Intergenerational Foundation, February 10th.

68. HM Treasury (2011), 'Reform of the Private Finance Initiative', December, p. 3. 
- inappropriate risk transfer raising the perceived risk to investors, and resulting in a high cost of capital; and

- lack of bank financing following the recent turmoil in the credit market.

The second and the third point, in particular, mean that when undertaking especially risky infrastructure investment, PPPs may not be the best procurement method. This leaves scope to discuss possible alternative financing methods in circumstances where PPPs are generally ineffective (see section 4 ).

This section has also argued that the oft-cited higher cost of capital of PPPs relative to the case of public provision may be unfounded. In particular, the claim that the government can raise money 'more cheaply' than the private sector is often based on the misconception that the government has to pay only for the debt risk associated with the project and not the equity risk. In reality, equity risk is passed on to the taxpayers, and is simply masked in the case of public provision. However, this risk is priced explicitly in the case of private sector provision. To the extent that the pricing is correct, there is nothing that would suggest that the government should be able to raise money more cheaply than the private sector. 


\section{THE RAB MODEL}

This section introduces the regulated asset base (RAB) model. One crucial difference between the RAB model and PPPs is that the former requires the presence of an independent regulator which, under directives from the government, seeks to ensure that companies act in a socially optimal way. With this in mind, this section introduces the concept of the RAB model and assesses its potential as a governance tool to promote infrastructure investment. A distinction is made between the RAB model as applied to existing capacity, and a model for new capacity, which could incorporate a role for a national infrastructure bank.

\subsection{What is a RAB model?}

The regulated asset base is a familiar concept in regulated utilities. It is an accounting number mainly used by economic regulators in the calculation of allowed returns. The RAB represents 'the regulated company's past investments, comprising what investors paid when the assets were originally privatised, plus the completed efficient CAPEX since then, adjusted for depreciation'. ${ }^{69}$ Thus, at any given time, the RAB refers to the cumulative historical investment made by the company, net of cash recovered from regulatory depreciation. The RAB is also usually indexed to a measure of price inflation in order to allow for the effects of inflation on the regulated company's capital stock over time.

Under the RAB model, investors are allowed to earn revenues which cover three elements.

- An allowance for the depreciation of the RAB over time, calculated according to established regulatory techniques (ie, a return of capital invested). Depreciation is calculated with reference to asset lives and can be straight line, front-loaded or backloaded according to the preference for the recovery of sunk costs over time. The choice of depreciation profile is NPV-neutral, but can be altered to reflect the allocation of risk between the company and customers, inter-generational equity, and efficient capacity utilisation.

- A return to investors based on the value of the RAB (ie, a return on capital invested). This has typically been calculated by multiplying the RAB by a weighted average cost of capital (WACC) (ie, an average of the cost of equity and the cost of debt). The WACC is intended to reflect the opportunity cost of the investments made by the investor.

- The forecast level of operating expenditure (OPEX) associated with the day-to-day operation of the network. These are compensated on a pay-as-you-go basis.

69. Helm, D. (2009), 'Infrastructure, investment and the economic crisis', published in D. Helm, J. Wardlaw and B. Caldecott (eds), Delivering a 21st Century Infrastructure for Britain, London: Policy Exchange, p. 35. 
The RAB has also been applied further afield as incentive regulation has become more frequently employed. However, there has been little exploration of the applicability of the RAB model beyond the regulated utility sector to facilitate, for example, infrastructure investments.

Crucially, the RAB model provides a guarantee to investors that they will earn a return not only on new CAPEX and OPEX, but also their sunk investments in the network. This guarantee typically takes the form of statutory legislation which places a duty on the independent regulatory body to ensure that it sets the company's allowed revenues such that the company can finance its regulatory functions (so long as it is run efficiently). Although it has never been formally tested, companies can have recourse to the courts in the event that the regulator does not meet its duty. It has thus been seen 'as a particularly credible and robust long-term contract ultimately guaranteed by law'. ${ }^{70}$ This feature means that the RAB model has the potential to solve the underinvestment problem in infrastructure largely resulting from the time-inconsistency problem.

\section{Figure 5.1. The Regulated Asset Base Model}

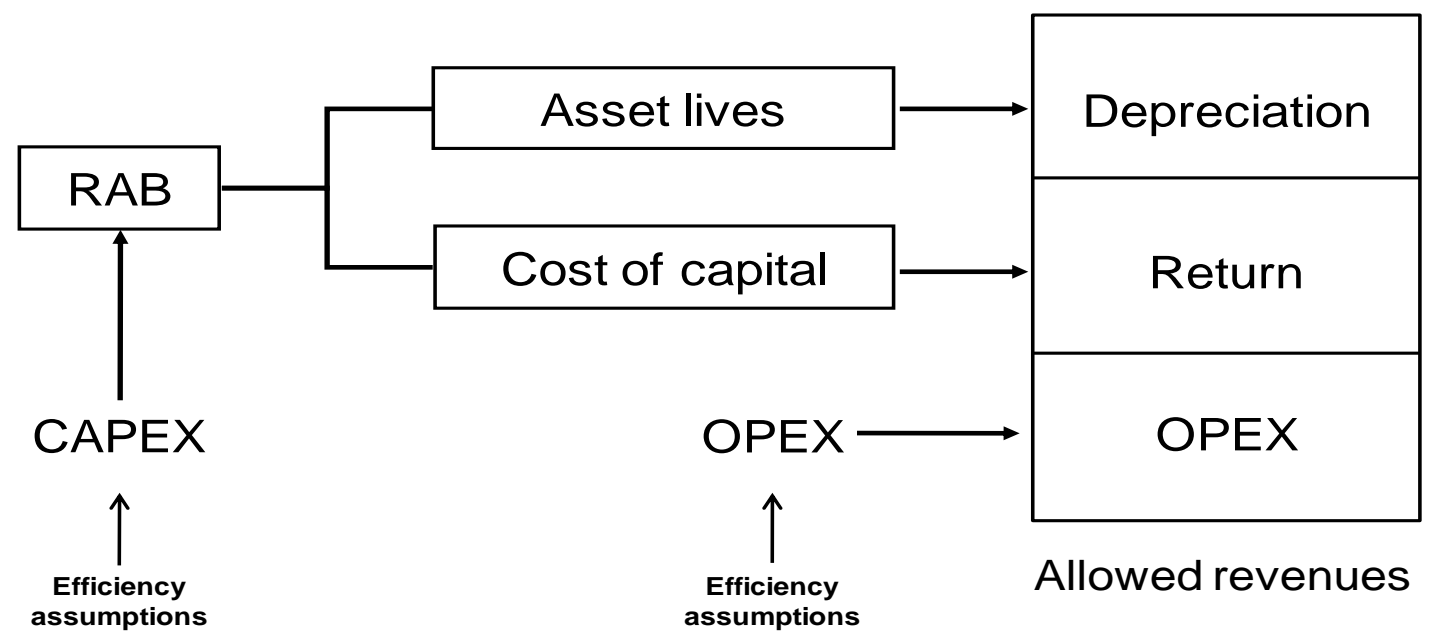

Source: Oxera

\subsubsection{The RAB model for existing capacity}

As noted, the RAB model was an offshoot of the privatisation and economic regulation of the utilities (ie, the energy transmission and distribution, telecoms, water, and rail sectors) in the UK. This typically involved first establishing the infrastructure operator as a government-owned company and establishing an economic regulator to set charges based on an indicative value of the asset prior to privatisation. This allowed regulated cash flows to be generated for investors to value prior to the flotation. The RAB was then reset at the first, post-privatisation price review based on market capitalisation. The allowed return was also typically lowered at the price review to reflect the fact that there was likely to be less risk (ie, less political, regulatory and commercial risk) once the frameworks were established.

Given the precedent set by these sectors, the RAB model is easily transferable to the roads sector and to other transportation infrastructure (eg, underground systems, highspeed rail lines, etc) for existing capacity.

70. Ibid., p. 317. 


\subsubsection{The RAB model for new capacity}

The traditional RAB model applied in the utility sector could also be extended to new infrastructure investments. Consider, for example, an asset that has been built, presumably under contracts closer to traditional government procurement. In order to apply the RAB model in this context, the government would have to repackage the asset at the refinancing point to sell on to new financial interests, potentially via a national infrastructure bank.

In this context, the repackaging might not necessarily have to be applied to only one 'infrastructure asset', but could instead incorporate an entire regional network (such as the roads example), or a collection of smaller, unrelated projects. If multiple projects are bundled, there would be potential for cross-subsidisation across projects, if this was considered necessary or desirable. This could be especially beneficial where a small project has significant economic benefits (ie, positive externalities) but is not commercially viable on its own (and thus would not be pursued by the private sector in isolation).

Under the RAB model, the assets owned by the private sector would be regulated by an independent economic regulator. Hence, the RAB and regulation are intertwined. The regulator would be responsible for calculating allowed revenues and setting allowed prices while reflecting the underlying business characteristics in the relevant sector. For example, regulation could be introduced in the form of a price cap, revenue cap or yield cap. These alternative forms differ in terms of the allocation of the demand risk: under a price cap regime, the volume element of demand risk is borne by the regulated company, while in the case of a revenue cap the demand risk is passed through to consumers in full in the form of a higher allowed price if outturn volumes are lower than forecast. ${ }^{71}$

\subsection{Potential benefits of the RAB model}

The main argument presented for the RAB model is that it is the most effective means of overcoming the time-inconsistency problem and thus should have investment benefits. The regulatory framework and commitment to the RAB have been crucial. In this context, the success of the RAB has been due to the fact that it is transparently calculated and the markets consider the regulator to be committed to it and to rewarding investors with a return equal to the cost of capital if the company meets the regulator's projections. This credibility has stemmed from the legal requirement for the regulator to ensure that the regulated company is able to finance its functions (so long as it is run efficiently).

It has been noted that under public finance the equity risk is effectively borne by taxpayers. Similarly, the explicit guarantee to the RAB effectively transfers equity risk to customers and taxpayers. ${ }^{72}$

Hence, by convincing shareholders that their investments are protected, and thus removing a substantial amount of investor risk, the RAB has been associated with a significantly lower cost of capital than for PPPs.

71. This is typically based on the assumption that consumers are willing to pay the higher price-ie, that there is sufficient excess demand for the products or services of the regulated company.

72. An example of this is the liabilities of Railtrack that fell on customers (in the form of higher charges) and taxpayers (in the form of greater subsidy) following the Hatfield derailment in the UK. 
This could lead to significant financing cost savings. For example, using the OECD (2006) estimates of the total investment requirement for the road and rail sectors over the next 18 years of around $\$ 5,400$ billion (assuming $\$ 300$ billion per year), a $1 \%$ reduction in the cost of capital would lead to a saving of $\$ 54$ billion per year. This is enough to cover the annual investment requirement for the rail sector in full.

Moreover, the cost of regulation under the RAB, which is equivalent to the transaction cost under PPPs, is quite modest compared with the turnover of industries that are regulated. In 2001, HM Treasury estimated that the cost of regulation was less than $0.2 \%$ of total industry turnover across all the UK regulators, ${ }^{73}$ whereas the transaction costs of the London Underground PPP were around $2.8 \%$ of the contract's NPV. In absolute terms, by 2009 the total cost of running the eight economic regulators in the UK was $£ 354.4 \mathrm{~m}$ per annum. ${ }^{74}$

The credibility of the guarantee surrounding the RAB would also potentially allow the government to tap into capital markets in a way that has not been possible for PPPs since the demise of the monoline insurers (see section 3.6). For example, an infrastructure bank might be set up to sell RAB-backed assets primarily to pension and life funds:

Pension and life funds should be encouraged to play a greater role in channelling savings into infrastructure projects. Pension and life funds are the principal vehicles for savings. They have long-term liabilities, and utilities have long-term time-inconsistency exposures and long-lived physical assets. The RAB provides a means through which savings can be channelled by financial institutions into infrastructure investments. ${ }^{75}$

The appropriateness of RAB-backed assets is increased by the fact that the RAB model is typically embedded within the RPI - $X$ framework. This means that the asset is essentially indexed-linked, thereby protecting it from inflation risk.

A further potential advantage of the RAB model is its flexibility relative to PPP contracts. While both types of contract require the majority of conditions and deliverables to be determined ex ante, the RAB model allows for revenue and cost assumptions to be revisited during price reviews (typically held every five years). At these (typically) quinquennial reviews, the regulator can revise its assumptions relating to the appropriate cost of capital, the efficient levels of OPEX and CAPEX, and so on. PPPs, by contrast, tend to be inflexible, and tend to be revised only in cases where the entire contract is renegotiated. As noted above, renegotiations create a moral hazard problem during the bidding stage, and can lead to overbidding. This problem is reduced in the RAB model.

Finally, several other potential advantages of the RAB model have been noted from its implementation in utilities regulation.

73. See HM Treasury (2001), 'External Efficiency Review of Utility Regulators', final report, February, p. xi.

74. This figure includes costs attributable to safety, as well as economic regulation. Calculated from the regulators' profit and loss accounts for financial year 2008/09 at current prices.

75. Helm (2009), 'Infrastructure, investment and the economic crisis', published in D. Helm, J. Wardlaw and B. Caldecott (eds), Delivering a 21st Century Infrastructure for Britain, London: Policy Exchange, p. 62. 
- As part of the RPI - X regulatory framework, it has been combined with strong incentives for efficiency in the delivery of investments (CAPEX) and operations maintenance expenditure. This, it has been argued, helps to overcome the problems of gold-plating associated with the rate-of-return regulation which has been widespread outside of the UK.

- The model facilitates a 'market for corporate control' as a mechanism for incentivising owners to exercise oversight and discipline over the management of the assets.

- It incentivises owners of the assets to maintain the long-run condition and hence the value of the assets.

- Although it is easier to apply the RAB/WACC model where a company provides only one service, this model is sufficiently flexible to be applied in the case of a company providing a number of services using a single asset base. This would be a significant advantage where disparate assets are bundled into a single RAB.

\subsection{Potential issues with the RAB model}

There are several issues with the RAB model, including the following.

- Initial RAB valuation. Central to the discourse following privatisation and the introduction of the RAB model has been asset valuation. In particular, privatisations have been affected by the question of how to provide an initial value for assets. UK regulators did not set a RAB value at the time of privatisation, but at subsequent price reviews calculated initial RAB values on the basis of the companies' flotation values (often averaged over a period of time). These market values were significantly lower than the net book value of assets, such that using net book values would have led to a sizeable redistribution between consumers and shareholders.

- Funding. The RAB model does not necessarily resolve the question of who ultimately pays for investments. The investor needs to be compensated with a return on their investment, which requires some form of dedicated revenue stream. In some sectors, notably roads, there may not be a clearly delineated revenue stream in the form of direct user charges. Consequently, the RAB model may need to be implemented alongside user charging (ie, road pricing) or some hypothecation of road taxes so as to establish an investor return. This is currently being discussed as part of the debate surrounding potential privatisation of the strategic road network in England.

- Public procurement. As discussed above, the RAB model is not proposed for greenfield projects. As such, one proposition is for greenfield investments to be undertaken through traditional public procurement methods (ie, with the private sector responsible only for construction in the first instance), and then to be sold on only once construction is complete (ie, when PPPs would typically be refinanced). However, this report has noted the potential disadvantages of traditional procurement techniques, including higher total life-cycle costs, lack of synergies, budgeting constraints and less developed risk evaluation. Improvements might need to be made to public procurement techniques to ensure that optimal investments were made. ${ }^{76}$

76. See, for example, Erridge, D., Fee. R and McIlroy, J. (eds) (2001), Best practice procurement: public and private sector perspectives, UK: Gower. 
- Bias towards higher gearing. In the standard RAB model, companies are allowed to earn their WACC on the RAB. However, this leaves scope for firms to earn rent through financial engineering. In particular, because the WACC is a weighted average cost of capital and cost of debt, if debt is cheaper than equity, the firm could earn a higher return by increasing its leverage. This also means that the equity incentive of companies may be eroded over time, thereby eroding the benefits of the profitmaximising motivation of the private sector.

- CAPEX bias. In some regulated industries, particularly the water and energy sectors, there has been a suggestion of a bias towards CAPEX rather than OPEX solutions, as the former is added to the RAB and earns a rate of return over time, while the latter is remunerated on a pay-as-you-go basis. ${ }^{77}$

\subsection{Summary}

This section has introduced the RAB model as a potential alternative means of overcoming the time-inconsistency problem inherent in infrastructure investment. It has highlighted the benefits and issues in applying the RAB model to infrastructure investment. What is clear from the analysis is that the RAB model, like PPPs, is not suitable under all circumstances, and that there are situations in which it may be inadequate.

It is worth nothing, however, that, in the regulation of UK utilities, the RAB model has provided a credible, legally backed guarantee to investors that they will earn a return on their (sunk) investments in the infrastructure network. The guarantee on the RAB has typically taken the form of a statutory duty on the independent regulatory body, requiring it to enable the company to finance its regulated functions. The credibility provided by this guarantee has effectively removed equity risk from investors and has thus allowed for debt financing closer to the level of government borrowing.

The RAB model could easily be transferred to existing capacity in other sectors. A more radical change would be required to apply the RAB model to new capacity. This could involve an infrastructure bank purchasing completed, publicly procured projects, repackaging them, and then selling them on to institutional investors. This could incorporate one, or a number of, projects, as necessary. This would, however, see a return to traditional public procurement-and its associated costs-for greenfield investment.

77. That is, OPEX is included in user charges at the time it is incurred but does not affect future charges. 


\section{WHEN IS THE PPP OR THE RAB MODEL MOST APPLICABLE?}

The prevalent use of PPPs by governments around the world has shed more light on their problems than their benefits. However, the question remains as to whether there are better alternatives to PPPs. The aim of this section is to consider the circumstances in which the RAB model may be preferred to PPPs. In assessing their relative advantages and disadvantages, the key areas to consider are:

- efficiency (both allocative and technical);

- flexibility;

- transaction costs;

- cost of financing;

- allocation and pricing of risk; and

- potential for incentives to be distorted.

Some of these areas are inherently related, but there is sufficient distinction between them to consider them separately. Table 5.1 considers each of these key areas in turn and assesses the appropriateness of PPPs and the RAB model.

The importance of the time-inconsistency problem in infrastructure investment when the private sector is involved has already been made clear. Both PPPs and the RAB model represent potential ways in which this problem may be solved-PPPs through long-term contracts, and the RAB through the legal requirement for the regulator to ensure that the infrastructure's functions can be properly financed. That is, they are both intended to remove the political/regulatory risk from the project; exactly how the market perceives the effectiveness of the risk transfer between the two methods may differ, and this difference in perception may lead to differences in the cost of financing between the two. Exactly how investors would view the two financing methods differently is an empirical question which is beyond the scope of this report.

Widespread use of PPPs has in part been due to the fact that they allow government to remove otherwise expensive investment from their PSBR. This, together with other, arguably more 'real' benefits of PPPs discussed in section 2, has led the government to set PPPs as the de facto way of financing infrastructure investment. The relative advantages of PPPs and the RAB model depend on the specifics of the investment project.

- The inherently inflexible nature of PPPs means that when future demand/usage or prices are uncertain, PPPs may prove to be a constricting factor in attempting to maximise social welfare. Under such circumstances, transactions costs are also likely to be large due to the difficulty in assessing contingencies and negotiating 
consequences. ${ }^{78}$ Moreover, the problems with the competitive tender process may be exacerbated for projects with a high degree of uncertainty. These factors may lead investors to require higher rates of return than otherwise, leading to excessively high costs of capital for PPP projects.

- Creating a regulator may not be feasible or appropriate in certain situations, especially when the infrastructure investment is not significant. The associated cost of regulation implies that, for relatively small projects, PPPs may represent better value for money than the RAB (assuming that transaction costs associated with such projects under PPPs are small).

- Past PPPs have exhibited a tendency to transfer too much risk to the private sector due to the reluctance of government departments to take on risk. This problem may be mitigated under the RAB model if the regulator can effectively retain its independence from the government.

Given that even a small saving in the cost of capital implies a large absolute saving due to the scale of the investment requirement, it is crucial to evaluate a number of options, including the RAB model, when financing infrastructure.

Note that the RAB model described in this report is suitable for brownfield investments. However, for greenfield investments, the RAB model does not solve the problem associated with the initial procurement process. In contrast, PPPs aim to solve the problem associated with public procurement as well as the management of ongoing operations. This overlap between the two methods of financing suggests that there may be potential for a hybrid approach of PPP and the RAB model that combines the benefits of the two.

78. As noted in section 4.2, the cost of regulation under the RAB, which is equivalent to the transaction cost under PPPs, is quite modest in comparison to the turnover of the industries which are regulated. 


\section{Table 5.1 Comparison of PPPs and the RAB models in the six key areas}

\section{Area}

Efficiency (both allocative and

technical)

Flexibility

Transaction cost
PPPs

- Allocative efficiency is achieved by the government being required to choose the socially optimal infrastructure investment, and is generally independent of financing method.

- Efficiency gain can arise only if the market failures associated with private sector provision of infrastructure can be addressed.

- Highly leveraged nature of infrastructure may lead to weaker profit-maximising motive.

- $\quad$ PPPs are necessarily long-term contracts requiring conditions and deliverables to be determined ex ante.

- These are, by design, inflexible to avoid potential problems during the bidding stages.

- Past experience suggests that transaction costs for PPPs can be large; both in terms of cost and time.

- Transaction costs represent around 3\% of the NPV of the project.

- If appropriately specified, the cost of capital for the project should only involve equity risk.

- However, in reality, the political/regulatory risk associated with PPPs tends to be high such that the cost of capital of PPPs is usually high.

\section{RAB model}

- To the extent that RPI - $X$, on which the RAB model is based, can encourage efficiency in the infrastructure sector, it should not suffer from (technical) efficiency problems.

- $\quad$ Price review controls associated with the determination of $X$ is transparent while being guided by economic principles, as compared with PPPs which are undertaken on a project-by-project basis.

- The RAB model requires ex ante specification of conditions and services.

- However, these can be revised during the price review process.

- These must follow sound economic principles, and although subject to potential abuse, imply that the RAB model is more flexible than PPPs.

- $\quad$ Transaction costs are replaced with regulatory costs.

- The cost of regulation is less than $0.2 \%$ of the turnover of the regulated industries.

- The credibility of the government stems from the legal requirement for the regulator to ensure that the company is able to finance its functions, which includes the RAB.

- To the extent that the indirect government guarantee for the RAB is more credible than government's commitment under PPPs, the cost of capital may be lower.

- The guarantee also implies that companies could issue RAB-backed assets, further enabling companies to raise finance more easily and cheaply. 


\section{Area}

Allocation and pricing of risk

PPPs

PPPs can potentially lead to optimal sharing of risks between the public and the private sector.

- In reality, the public sector has looked to push as much risk as possible on to the private sector, regardless of which party is best able to manage that risk.

- The effect is to push up the cost of capital.

- One advantage is that the equity risk associated with the project is explicitly priced by the market in the cost of finance.

Potential for incentives to be distorted
- Incompleteness of PPP contracts may mean that firms behave in an opportunistic way.

- $\quad$ Bidding processes in the past seem to have led to over-confident project estimates, in turn leading to forced renegotiations in the future.

- $\quad$ The government's incentive in using PPPs may also be distorted by the fact that PPPs have traditionally not been recorded as part of the PBSR.

\section{RAB model}

- Problem of passing too much risk to the private sector may be mitigated if the regulator acts appropriately.

- In much the same way as the Bank of England enjoys independence from the government, regulators could be made independent so as to ensure optimal risk-sharing.

- Similar to PPPs, the RAB model also makes explicit the equity risk associated with the project.

- $\quad$ Any mis-pricing may be resolved in the next price control review, implying lower overall risk.

- $\quad$ Allowing firms to earn the WACC on their RAB may lead them to increase their gearing over time.

- This may inappropriately increase the bargaining power of the company over the regulator/government.

- $\quad$ There may be a bias towards CAPEX rather than OPEX solutions.

- Unless regulators can be sufficiently independent of the government, the political cycle effect may impede the ability of the RAB model to solve the time-inconsistency problem.

- Similarly, the regulators must be sufficiently independent of the private sector to avoid regulatory capture.

Source: Oxera analysis and in previous sections. 


\section{BIBLIOGRAPHY}

Averch, H. and Johnson, L. (1962), 'Behaviour of the firm under regulatory constraint', American Economic Review, 52:5, 1052-1069.

Baeza, M.A. and Vassallo, J.M. (2008), 'Traffic Uncertainty in Toll Motorway Concessions in Spain: an Analysis of the Ramp-up Period', TRANSyT working paper, 2008-01, 1-18.

Bain, R. (2009), 'Error and Optimism Bias in Toll Road Traffic Forecasts', Transportation, 36: 5, 469-82.

Blanc-Brude, F., Goldsmith, H. and Välilä, T. (2008), 'Public Private Partnerships in Europe: An Update', European Investment Bank, Economic \& Financial Report 2007/03, Economic and Financial Studies, Luxembourg.

Coase, R.H. (1960), 'The Problem of Social Cost', The Journal of Law and Economics, 3, 1-44.

Cowen, T. and Parker, D. (1997), 'Markets in the Firm: A Market-Process Approach to Management', Hobart Paper No. 134. Institute of Economic Affairs, London.

Egert, B., Araujo, S. and Kozluk, T. (2009), 'Infrastructure and growth: empirical evidence', OECD Economics Department Working Papers, No.685.

European PPP Expertise Centre (2009), 'The financial crisis and the PPP market: Potential Remedial Actions', August.

European PPP Expertise Centre (2010), 'Capital markets in PPP financing: Where we were and where are we going', March.

Flyvbjerg, B. Holm, M.S. and Buhl, S. (2005), 'How (in)accurate are demand forecasts in public works projects? The case of transportation', Journal of the American Planning Association, 71:2, 131-46.

Gaffney, D. and Pollock, A.M. (1999), 'Pump-Priming the PFI: Why are Privately Finance Hospital Schemes Being Subsidized', Public Money and Management, 19:1

Grimsey, D. and Lewis, M.K. (2004), Public Private Partnerships: The Worldwide Revolution of Infrastructure Provision and Project Finance, Cheltenham: Edward Elgar.

Grimsey, D. and Lewis, M.K. (2007), 'Public private partnerships and public procurement', Agenda, 14:2, 171-188.

Grout, P.A. (1997), 'The Economics of the Private Finance Initiative', Oxford Review of Economic Policy, 13:4, 53-66. 
Guasch, J.L. (2004), 'Granting and Renegotiating Infrastructure Concessions - Doing it Right', World Bank Institute Development Studies, 28816

Hart, O.D. (1991), 'Incomplete contracts and the theory of the firm', in O.E. Williamson and S.G. Winter (eds), The Nature of the Firm, Oxford: Oxford University Press, 138-159.

Helm, D. (2009), 'Utility regulation, the RAB and the cost of capital', May 6th.

Helm, D. (2009), 'Infrastructure investment, the cost of capital, and regulation: an assessment', Oxford Review of Economic Policy, 25:3,

Helm, D. (2009), 'Infrastructure, investment and the economic crisis', published in D. Helm, J. Wardlaw and B. Caldecott (eds), Delivering a 21st Century Infrastructure for Britain, London: Policy Exchange

Helm, D. (2010), 'Infrastructure and infrastructure finance: The role of the government and the private sector in the current world', EIB Papers, 15:2, 8-27.

HM Treasury (2001), 'External Efficiency Review of Utility Regulators', final report, February, p. xi.

HM Treasury (2011), 'Reform of the Private Finance Initiative', December.

House of Commons Economic Policy and Statistics Section (2003), 'The Private Finance Initiative (PFI)', Research paper 03/79, October 21st.

Jenkinson, T. (2003), 'Private Finance', Oxford Review of Economic Policy, 19:2, 323334.

Kessides, I. (2005), 'Infrastructure Privatization and Regulation: Promises and Perils', The World Bank Research Observer, 20:1

Kydland, F. and Prescott, E. (1977), 'Rules rather discretion: The inconsistency of optimal plans', Journal of Political Economy, 87, 473-492.

Li, Z. and Hensher, A. (2010), 'Toll Roads in Australia: An Overview of Characteristics and Accuracy of Demand Forecasts', Transport Reviews, 30:5.

OECD (2006), 'Infrastructure to 2030: Telecom, Land Transport, Water and Electricity', June 30th.

OECD (2008), Public-Private Partnerships: In Pursuit of Risk Sharing and Value for Money, OECD Publishing.

Oxera (2009), 'What is the contribution of aviation to the UK economy?', final report prepared for Airport Operators Association, November.

Oxera and RBconsult (2012), 'Disincentivising overbidding for toll road concessions', prepared for Department of Infrastructure and Transport, April.

Parker, D. and Hartley, K. (2003), 'Transaction costs, relational contracting and public private partnerships: a case study of UK defence', Journal of Purchasing \& Supply Management, 9, 97-108. 
Parker, D. (2012), 'The Private Finance Initiative and Intergenerational Equity', on behalf of The Intergenerational Foundation, February 10th.

Pickrell, D.H. (1990), 'Urban rail transit projects: Forecast versus actual ridership and cost', US Department of Transportation.

Sappington, D. and Stiglitz, J.E. (1987), 'Privatization, Information and Incentives', Journal of Policy Analysis and Management, 6, 567-82.

Simon, H. (1957), 'A Behavioural Model of Rational Choice', in Models of Man, Social and Rational: Mathematical Essays on Rational Human Behaviour in a Social Setting, New York: Wile. 
